DOI: $10.20472 / \mathrm{TE} .2015 .3 .3 .002$

\title{
THE IMPORTANCE OF VOCABULARY IN LANGUAGE LEARNING AND HOW TO BE TAUGHT
}

\section{MOFAREH ALQAHTANI}

\begin{abstract}
:
Vocabulary learning is an essential part in foreign language learning as the meanings of new words are very often emphasized, whether in books or in classrooms. It is also central to language teaching and is of paramount importance to a language learner. Recent research indicate that teaching vocabulary may be problematic because many teachers are not confident about best practice in vocabulary teaching and at times don't know where to begin to form an instructional emphasis on word learning (Berne \& Blachowicz, 2008)

In this article, I summarizes important research on the impotence of vocabulary and explaining many techniques used by English teachers when teaching English, as well as my own personal view of these issues.
\end{abstract}

\section{Keywords:}

Vocabulay

\section{Authors:}

MOFAREH ALQAHTANI, King Khaled Academy, Saudi Arabia, Email: mqahtani2004@yahoo.com

\section{Citation:}

MOFAREH ALQAHTANI (2015). The importance of vocabulary in language learning and how to be taught . International Journal of Teaching and Education, Vol. III(3), pp. 21-34.,

10.20472/TE.2015.3.3.002 


\section{Introduction}

Vocabulary, as one of the knowledge areas in language, plays a great role for learners in acquiring a language (Cameron, 2001). Harmon, Wood, \&Keser, (2009) as well as Linse (2005) statethat learners' vocabulary development is an important aspect of their language development.Although it has been neglected for a long time, researchers have increasingly been turning their attention to vocabulary e.g. Carter and McCarthy (1988), Nation (1990), Arnaud and Bejoint (1992), Huckin, Haynes and Coady (1995), Coady and Huckin (1997), Schmitt $(1997,2000)$ Read (1997).

\section{Literature Review}

\section{The importance of learning vocabulary}

Vocabulary knowledge is often viewed as a critical tool for second language learners because a limited vocabulary in a second language impedes successful communication. Underscoring the importance of vocabulary acquisition, Schmitt (2000) emphasizes that "lexical knowledge is central to communicative competence and to the acquisition of a second language" p. 55)

Nation (2001) further describes the relationship between vocabulary knowledge and language use as complementary: knowledge of vocabulary enables language use and, conversely, language use leads to an increase in vocabulary knowledge.

The importance of vocabulary is demonstrateddaily in and out the school. In classroom, the achieving students possess the most sufficient vocabulary.

Researchers such asLaufer and Nation (1999), Maximo (2000), Read (2000), Gu (2003), Marion (2008) and Nation (2011) and others have realised that the acquisition of vocabulary is essential for successful second language use and plays an important role in the formation of complete spoken and written texts. In English as a second language (ESL) and English as a foreign language (EFL) learning vocabulary items plays a vital role in all language skills (i.e. listening, speaking, reading, and writing (Nation,2011).Rivers and Nunan (1991), furthermore, argue that the acquisition of an adequate vocabulary is essential for successful second language use because without an extensive vocabulary, we will be unable to use the structures and functions we may have learned for comprehensible communication.

Research has shown that second language readers rely heavily on vocabulary knowledge and the lack of that knowledge is the main and the largest obstacle for L2 readers to overcome (Huckin,1995). In production, when we have a meaning or concept that we wish to express, we need to have a store of words from which we can select to express this meaning or concept. "When students travel, they don't carry grammar books, they carry dictionaries" (Krashen, as cited in Lewis, 1993, p25Many researchers argue that vocabulary is one of the most important-if not the most important- components in learning a foreign language, and foreign language curricula must reflect this. Wilkins (1972) states that: "There is not much value in being able to produce grammatical sentences if one has not got the vocabulary that is needed to convey what one wishes to say ... While without grammar very little can be conveyed, without vocabulary nothing can be conveyed" p97).Other 
scholars such as Richards (1980) and Krashen (1989), as cited in Maximo (2000)state many reasons for devoting attention to vocabulary. "First, a large vocabulary is of course essential for mastery of a language. Second language acquirers know this; they carry dictionaries with them, not grammar books, and regularly report that the lack of vocabulary is a major problem".

On the other hand, vocabulary has been acknowledged as L2 learners' greatest single source of problems (Meara, 1980). This remark may possibly reflect that the openendedness of a vocabulary system is perceived to be a cause of difficulty by learners. Another possible reason is that, unlike syntax and phonology, vocabulary does not have rulesthe learners may follow to acquire and develop their knowledge. In other words, it is not clear in L2 vocabulary learning what rules apply or which vocabulary items should be learned first. Oxford (1990)also claims that vocabulary is "by far the most sizeable and unmanageable component in the learning of any language, whether a foreign or one's mother tongue, because of tens of thousands of different meanings" Despite these difficulties that language learners face in L2 vocabulary, they still have to deal with it in their examinations as "vocabulary has traditionally been one of the language components measured in language tests" (Schmitt, 1999, 189). Furthermore, many learners see second language acquisition (SLA) as essentially a matter of learning vocabulary and therefore they spend a great deal of time on memorising lists of $L 2$ words and rely on their bilingual dictionary as a basic communicative resource. As a result, language teachers and applied linguists now generally recognise the importance of vocabulary learning and are exploring ways of promoting it more effectively. Some of this research takes the form of investigation of strategies learners use specifically for vocabulary (VLS), which is our focus of attention.

\section{English in the Saudi Educational System}

In the field of education, including English (from personal experience), education in Saudi Arabia is still dominated by the view that knowledge is a set of facts that have to be memorized. Teaching learning process as focuses on the teacher as a prominent source of knowledge. As a result, students may have problems to understand academic concepts as what they usually get is something abstract. Many students can serve a good level of memorization of teaching material but in the end of teaching learning process," they actually do not understand it at all.Nation (2011) statesKnowledge "is constructed by humans. Knowledge is not a set of facts, concepts, or laws waiting to be discovered. It is not something that exists independent of knower. Humans create or construct knowledge as they attempt to bring meaning to their experience. Everything that we know, we have made. Based on this opinion, a learning process that focuses on the teacher is no longer suitable. It is because our brain is continuously finding meaning and saving meaningful cases, and learning processes haveto involve students in finding meaning.

Teaching and learning processes have to make it possible for the students tounderstand the meaning of their learning material.Students as the learning subject are the starting point in teaching andlearning, which measure the success of the teaching learning process. Teachingand learning can be successful when the students can directly feel the advantagesof learning materials by experiencing and learning it. 
Going back to English in the Saudi educational system, children are eligible to go school consisting of pre-school, six years of primary school starting at the age of seven, and three years of intermediate (aged 13-15) and high (secondary) school (aged 16-18). English as a foreign language was added to the curriculum starting from the $4^{\text {th }}$ grade of primary school (age 9). Students receive four 45-minutes lessons of English per week and they have to pass examinations in all subjects, including English, to move from one level to another.

From my personal experience over the many years I have been teaching in Saudi Arabia, I have become more and more aware that some of the most basic principles of vocabulary teaching and learning have been forgotten or ignored. In other words, I found that although teaching still focuses more on grammar than on vocabulary, students majoring in English rely heavily on their knowledge of vocabulary rather than on their knowledge of grammar in learning English. The more vocabulary students have at their disposal, the better they learn, regardless of their grammatical knowledge, although this is not to say that they should neglect grammar completely.

\section{Teaching vocabulary}

Recent research indicates that teaching vocabulary may be problematic because many teachers are not confident about the best practice in vocabulary teaching and at times do not know where to begin to form an instructional emphasis on word learning (Berne \&Blachowicz, 2008). Teaching words is a crucial aspect in learning a language as languages are based on words (Thornbury, 2002). It is almost impossible to learn a language without words; even communicationbetween human beings is based on words. Both teachers and students agree that acquisition of the vocabulary is a central factor in teaching a language (Walters, 2004). Teaching vocabulary is one of the most discussed parts of teaching English as a foreign language. When the teaching and learning process takes place, problems wouldappear to the teachers. They have problems of how to teach students in order to gainsatisfying results. The teacher should prepare and find out the appropriatetechniques, which will be implemented to the students. A good teacher should preparehimself or herself with various and up-to-date techniques. Teachers need to be able to master thematerial in order to be understood by students, and make them interested andhappy in the teaching and learning process in the classroom.

The teachers should be concerned that teaching vocabulary is something newand different from student's native language. They also have to take into account thatteaching English for young learners is different from adults. The teachers have toknow the characteristics of his her learners. They moreoverneed to prepare goodtechniques and suitable material in order to gain the target of language teaching.

\section{The Description of Vocabulary}

\section{The Definition of Vocabulary}

Vocabulary can be defined as " words we must know to communicate effectively; words in speaking (expressive vocabulary) and words in listening (receptive vocabulary)" (Neuman\&Dwyer, 2009, p. 385). Hornby (1995)defines vocabulary as "the total number of 
words in a language; vocabulary is a list of words with their meanings". While Ur (1998)states: "Vocabulary can be defined, roughly, as the words we teach in the foreign language. However, a new item of vocabulary may be more than just a single word: for example, post office, and mother-in-law, which are made up of two or three words but express a single idea. A useful convention is to cover all such cases by talking about vocabulary "items"rather than "words."In addition, Burns (1972)defines vocabulary as" the stock of words which is used by a person, class or profession. According to Zimmerman cited in Coady and Huckin (1998)'vocabulary is central to language and of critical importance to the typical language learning. Furthermore, Diamond and Gutlohn (2006) in www.readingrockets.org/article state that vocabulary is the knowledge of words and word meanings."

From the definitions above, it can be concluded that vocabulary is the total number of words that are needed to communicate ideas and express the speakers' meaning. That is the reason why it is important to learn vocabulary.

\section{Kinds of Vocabulary}

Some experts dividevocabulary into two types: active and passive vocabulary. Harmer (1991) distinguishes between these two types of vocabulary. The first type of vocabulary refers to the one that the students havebeen taught and that they are expected to be able to use. Meanwhile, the second one refers to the words which the students will recognize when theymeet them, but which they will probably not be able to pronounce.Haycraft, quoted by Hatch and Brown (1995), indicate two kinds of vocabulary, namely receptive vocabulary and productive vocabulary.

\section{a. Receptive Vocabulary}

Receptive vocabulary is words that learners recognize and understand when they are used in context, but which they cannot produce. It is vocabulary that learners recognize when they see or meet in reading text but do not use it in speaking and writing (Stuart Webb, 2009).

\section{b. Productive Vocabulary}

Productive vocabulary is the words that the learners understand and canpronounce correctly and use constructively in speaking and writing. It involves what is needed for receptive vocabulary plus the ability to speak or write at the appropriate time. Therefore, productive vocabulary can be addressed as an active process, because the learners can produce the words to express their thoughts to others (Stuart Webb, 2005). 


\section{Vocabulary Mastery}

In order to understand the language, vocabulary is crucial to be mastered by the learner. Vocabulary mastery is needed to express our ideas and to be able to understand other people's sayings.According to Webster (1992)mastery refers to (1) a. the authority of a master: dominion, b. the upper hand in a contest or competition; superiority, ascendancy and (2) a. possession or display or great skill or technique, b. skill or knowledge that makes one master of a subject comment. While Hornby (1995)defines mastery as complete knowledge or complete skill. From that definition, mastery means complete knowledge or great skill that makes someone a master in a certain subject.

The specificity of any individual's vocabulary knowledge depends on the

person and his motivation, desires, and need for the words (Hatch and Brown, 1995). Vocabulary mastery refers to the great skill in processing words of alanguage. It is an individual achievement and possession (Rivers, 1989) For that reason, the biggest responsibility in increasing the knowledge is in theindividual himself. The success in widening the vocabulary mastery requires their own motivation and interest on the words of a language. From the definition above, we can conclude that vocabulary mastery is an individual's great skill in using words of a language, which is acquired based on their own interests needs and motivation. vocabulary mastery plays an important role in the four language skills and it has to be considered that vocabulary mastery is one of the needed components of language.

\section{The Techniques in Teaching Vocabulary}

This section reports on research results aimed at investigating the techniques used by a teacher of English in presenting the meaning and form of vocabulary.

Commonly, there are several techniques concerning the teaching of vocabulary. However, there are a few things that have to be remembered by most English teachers if they want to present a new vocabulary or lexical items to their students. It means that the English teachers want students to remember new vocabulary. Then, it needs to be learnt, practiced, and revised to prevent students from forgetting. Techniques employed by teachers depend on some factors, such as the content, time availability, and its value for the learners (Takač, 2008). This makes teachers have some reasons in employing certain techniques in presenting vocabulary.In presenting one planned vocabulary item, the teacher usually combined more than one technique, instead of employing one single technique. Teachers, furthermore, are suggested to employ planned vocabulary presentation as various as possible (Pinter, 2006).

Here are some techniques of teaching vocabulary as stated by Brewster, Ellis, and Girard (1992).

\section{a. Using Objects}

Using this technique includes the use of realia, visual aids, and demonstration. They can function to help learners in remembering vocabulary better, because our memory for objects and pictures is very reliable and visual techniques can act as cues for remembering words 
(Takač, 2008). In addition, Gairns\&Redman(1986) statethat real objects technique is appropriately employed for beginners or young learners and when presenting concrete vocabulary.

Objects can be used to show meanings when the vocabulary consist of concrete nouns. Introducing a new word by showing the real object often helps learners to memorize the word through visualization. Objects in the classroom or things brought to the classroom can be used.

\section{b. Drawing}

Objects can either be drawn on the blackboard or drawn on flash cards. The latter can be used again and again in different contexts if they are made with cards and covered in plastic. They can help young learners easilyunderstand and realize the main points that they have learned in the classroom.

\section{c. Using Illustrations and Pictures}

Pictures connect students' prior knowledge to a new story, and in the process, help them learn new words. There are plenty of vocabularies that can be introduced by using illustrations or pictures. They are excellent means of making the meaning of unknown words clear. They should be used as often aspossible. The list of pictures includes: posters, flashcards, wall charts, magazine pictures,board drawings, stick figures and photographs. Pictures for vocabulary teaching come from many sources. Apart fromthose drawn by the teacher or students, they are sets of colourful pictures intended for schools. Picturescut out of newspapers and magazines are very useful as well. Nowadays many readers, vocabulary books and coursebooks contain a vast number of attractive pictures that present the meaning of basic words. The teacher can use learning materials provided by the school. They can also make their own visual aids or used pictures from magazines. Visual support helps learners understand the meaning and helps to make the word more memorable.

\section{d. Contrast}

Some words are easily explained to learnersby contrasting it with itsopposite, for instance, the word" good" contrasted with the word "bad". But some words are not. It is almost impossible to contrast the words whose opposite is the gradable one. When the word "white"iscontrasted with the word "black", there is an "in between" word" grey". Furthermore, verb "contrast" means to show a difference, like photos that reveal how much weight someone lost by contrasting the "before" and "after" shots

Manymore studies have also shown that vocabulary is best acquired if it is similar to whatis already learnt (e.g. Rudska et al., 1982, 1985), it is not surprising that learningsynonyms is a way to expand our vocabulary.Learning about synonyms is important also because this is how dictionaries areorganised. Putting bilingual dictionaries aside, mono-lingual 
dictionariesessentially use words to explain words, and in this process, synonyms are often used(Ilson, 1991).

\section{e. Enumeration}

An enumeration is a collection of items that is a complete, ordered listing of all of the items in that collection. It can be used to present meaning.. In other words, this technique helps when any word is difficult to explain visually. We can say"clothes" and explain this by enumerating or listing various items. Teacher may list a number of clothes e.g.adress,a skirt,trousers etc ,and then the meaning of the word "clothes" will became clear.The same is true of 'vegetable'or"furniture", 'for example(Harmer 1991).

\section{f. Mime, Expressions and Gestures}

Klippel (1994) implies that "mime or gesture is useful if it emphasizes the importance of gestures and facial expression on communication. At the essence it can not only be used to indicate the meaning of a word found in reading passage, but also in speaking activity as it stresses mostly on communication.Many words can be introduced through mime, expressions, and gestures. For example, adjectives: "sad" ," happy"; mime and taking a hat off your head toteach hat and so on.

Several studies have emphasised the role of gestures in second language (L2) acquisition (Gullberg, 2008). Teachers tend to gesture a lot (Sime, 2001; Hauge, 1999), especially when addressing young learners and/or beginners. It is commonly acknowledged that "teachinggestures"capture attention and make the lesson more dynamic. Using analyses of video recordings of English lessons to French students, Tellier (2007) determined three main roles for teaching gestures: management of the class (to start/end an activity, to question students, request silence, etc.), evaluation (to show a mistake, to correct, to congratulate, etc.) and explanation to give indications on syntax, underline specific prosody, explain new vocabulary, etc.). Teaching gestures appear in various shapes: hand gestures, facial expressions, pantomime, body movements, etc. They can either mime or symbolise something and they help learners to infer the meaning of a spoken word or expression, providing that they are unambiguous and easy to understand. This teaching strategy is thus relevant for comprehension (Tellier, 2007). However, its utility may depend on the kind of gesture used by the teacher. It has been highlighted that foreign emblems, for instance, may lead to misunderstandings when it is not known by the learners (Hauge, 1999; Sime, 2001).

In addition to supporting comprehension, teaching gestures may also be relevant for learners'memorisation process. Indeed, many second language teachers who use gestures as a teachingstrategy declare that they help learners in the process of memorising the second language lexicon. Many of them have noticed that learners can retrieve a word easily when the teacher produces the

gesture associated with the lexical item during the lesson. Others have seen learners(especially young ones) spontaneously reproducing the gesture when saying the word. The effect ofgestures on memorisation is thus something witnessed by many but hardly explored on a systematic and empirical basis(Tellier, 2008). 


\section{g. Guessing from Context}

Guessing from context as a way of dealing with unfamiliar vocabulary in unedited selectionshas been suggested widely by L1 and L2 reading specialists (Dubin, 1993). Nation and Coady (1988) claim that there are two types ofcontexts. The first type is the context within the text, which includes morphological,semantic and syntactic information in a specific text, while the second one is the general context, ornon-textual context, which is the background knowledge the reader has about the subjects beingread. Williams (1985) agrees with Nation and Coady in considering the specific context as "theother words and sentences that surround that word..... it follows that other words in the context ofthe unfamiliar word often 'throw light on' its meaning. These other words can be found in thesentence containing the unknown word or other sentences beyond the sentence of the unknownitem. Similarly, McCarthy (1988) sees context as within the text itself i.e. the morphological,syntactic, and discourse information, which can be classified and described in terms of generalfeatures. Learning from context not only includes learning from extensive reading, but alsolearning from taking part in a conversation, and learning from listening to stories, films, televisionor the radio (Nation, 2001). In order to activate guessing in a written or spoken text, there should befour elements available: the reader, the text, unknown words, and clues in the text including someknowledge about guessing. The absence of one of these elements may affect the learner's ability toguess. Furthermore, this technique encourages learners to take risks and guess the meanings of words they do not know as much as possible. This will help them build up their self-confidence so that they can work out the meanings of words when they are on their own. There are many clues learners can use to establish meanings for themselves, such as illustrations, similarity of spelling or sound in the mother tongue, and general knowledge(Walters, 2004).

\section{Eliciting}

This technique is more motivating and memorable by simply giving pupils a list of words to learn.

\section{j. Translation}

Even though translation does not create a need or motivation of the learners to think about word meaning (Cameron, 2001), in some situations translation could be effective for teachers, such as when dealing with incidental vocabulary (Thornbury, 2002), checking students' comprehension, and pointing out similarities or differences between first and second language, when these are likely to cause errors (Takač, 2008). There are always some words that need to be translated and thistechnique can save a lot of time.

\section{4) Scales}

After the students have learnt two contrasted or related gradable items, this can be a useful way of revising and feeding in the new items. 


\section{5) Examples of the Type}

To illustrate the meaning of subordinates, such as flowers, vegetables, and foods, it is a common procedure to exemplify them e.g. rose, jasmine, and orchid are all flowers. But the technique cannot be applied in delivering the words that belong to more than one ordinate.

\section{Drilling}

Drilling is employed to make learners get accustomed to the word form especially to how it sounds. To make learners more familiar with the word, drilling should be clear and natural (Thornbury, 2002). Drilling is very necessary since learners need to say the word to themselves as they learn it to recall the words from memory (Ellis \& Beaton, 1993, in Read, 2000).

\section{Spelling the Word}

The primary means of spelling is actually memorizing words (Reed, 2012). Word spelling needs to be considered since spelling forms of English words is not always inferred by the pronunciation.

\section{Learners' Active Involvement}

Employingthis technique, the teacher encourages the students to find out word's meaning by elicitation (Takač, 2008). Elicitation maximizes learners' speaking opportunities, and acts as a way of checking learners' understanding (Thornbury, 2002). This technique also includes personalization, which is using the word by learners in a context or sentence that is related to their life.

Related to theabove techniques, Pinter (2006) argues that teachers are suggested to conduct planned presentations of vocabulary as various as possible,so it is better that teachers present word meaning and form by combining more than one technique. In addition, Takač (2008) points out that in choosing which techniques to be used in the classroom, teachers consider time availability, the content or teaching material.

\section{Vocabulary learning strategies}

Beside the above techniques, there are also, vocabulary learning strategies that teachers can take into account. They can train their students to use these strategies. Schmitt and McCarthy (1997) propose strategies to learn vocabulary as follows: (1) guessing from context, (2) using word parts and mnemonic techniques to remember words, and (3) using vocabulary cards to rememberforeign language-first language word pairs. It is supported by Murcia (2001) who also proposes three strategies to learn vocabularies. The firststrategy is guessing meaning from context; she says that a context is rich enough to give adequate clues to guess the word's meaning. The secondstrategy is mnemonic devices: she proposes 
keyword technique. When seeing or hearing the target word, the learner is reminded of the keyword. The thirdstrategy is vocabulary notebooks; she suggests a memory aid in independent learning by setting up vocabulary notebooks.

Based on the techniques used for presenting new vocabulary and vocabulary learning strategies, the experts suggest lots more techniques that are claimed to be helpful for students to learn vocabulary in an easier way. What the researcher sees as better way to teach vocabulary is by learning in rich contexts. According to Stahl (2005) in http://www.readingrockets.org, students probably have to see a word more than once to place it firmly in their long-term memories. This does not mean more repetition or drilling of the word, but seeing the word in different and multiple contexts.

Finally, teachers may encourage students to keep a vocabulary notebook because a great deal of vocabularygrowth ultimately depends on the learner. They may have students who aresuccessful vocabulary language learners share their notebook methods. For students who needhelp, they can demonstrate how to set up a vocabulary notebook that is neat and organized in a mannerthat will facilitate multiple retrievals of the words. If the notebook is not set up well, thenlearners are less likely to practice the words, which defeats the purpose of keeping thenotebook in the first place.

Moreover, in presenting one planned vocabulary item, the teacher usually combine more than one technique, instead of employing one single technique. Teachers are suggested to employ planned vocabulary presentations as various as possible (Pinter, 2006).

\section{Conclusion}

This piece of work aims to highlight the importance of vocabulary learning as an essential part in foreign language learning. Although it has been neglected for many decades, during the 80 s it became a 'hot' topic for researchers. Lexical knowledge is central to communicative competence and to the acquisition of a second/foreign language and a lack ofvocabulary knowledge is an obstacle to learning.

An attempt is made to review the trends in the area of teaching vocabulary through various techniques ESL/EFL teachers use when teaching .Before presenting the meaning or form of vocabulary items, teachers need to notice the type of the vocabulary, the students' level and characteristics, and also the value of the techniques for the learners. In other words, students' age, level of education as well as English proficiency ...etc may affect their learning, so teachers need to be aware of these differences when applying their teaching technique's. They can further provide their students with vocabulary learning strategies with opportunities to encounter words repeatedly and in more than one context.

\section{References}

ALI A. ALSAAW, (I2013) To what extent guessing the meaning from the context, is helpful in teaching vocabulary. ARECLS, , Vol.10, 130-146.

Annisa, A., (2013) Techniques in presenting vocabulary to young EFL learners. Journal of English and Education, 1(1), 11-20 
Arnaud, P. \&Bejoint, H. (1992).Vocabulary and Applied Linguistic. Basingstoke: Macmillan. Berne, J. I., \&Blachowicz, C. L. Z.,(2008)What reading teachers say about vocabulary instruction: Voices from the classroom. The Reading Teacher 62 (4).314-323.

Cameron, L. (2001). Teaching languages to young learners. Cambridge: Cambridge University Press.

Coady, J., \&Huckin, T. (Eds.).(1997). Second language vocabulary acquisition. Cambridge: Cambridge University Press.

Carter, R. (1987). Vocabulary: Applied linguistic perspectives. London: Allen and Unwin.

Carter, R., \& McCarthy, M. (Eds.).(1988). Vocabulary and language teaching. London: Longman.

Cameron, L. (2001). Teaching languages to young learners. Cambridge: Cambridge University Press.

Dubin, F. (1993).Predicting word meanings from contextual clues: Evidence from L1 readers.In Huckin, T., Haynes, M., and Coady, J (Ed.), Second language reading and vocabulary learning (pp. 181-202). Norwood, N.J.: Ablex.

Folse, K. (2004). Vocabulary Myths: Applying Second Language Research to ClassroomTeaching. Ann Arbor: The University of Michigan Press.

Gairns, R. \& Redman, S. (1986). Working with words: A guide to teaching and learning vocabulary.USA: Cambridge University Press.

$\mathrm{Gu}, \mathrm{Y}$. (2003a). Vocabulary learning in second language: person, task, context and strategies.Electronic Journal. TESL-EJ, 7, 2, 1-26.

$\mathrm{Gu}, \mathrm{Y}$. (2003b). Fine brush and freehand: The vocabulary learning art of two successful Chinese EFL learners. TESOL Quarterly, 37, 73-104.

Gruneberg, M. and Sykes, R. (1991).Individual differences and attitudes to the keyword method of foreign language learning. Language Learning Journal, 4, 60-62.(Harmer 1991).

John Read (2004). 7. RESEARCH IN TEACHING VOCABULARY. Annual Review of Applied Linguistics, 24, pp 146-161. doi:10.1017/S0267190504000078.

Harmon, J. M., Wood, K. D.,,\&Keser, K. (2009) Promoting vocabulary learning with interactive word wall. Middle School Journal, 40(3), 58-63.

Hatch, E. \& Brown, C. (1995).Vocabulary, Semantics, and Language Education. Cambridge: Cambridge University Press.

Hauge, Elizabeth (1999). Some common emblems used by British English teachers in EFL classes. In Killick, David \& Margaret Parry (Eds.), Cross-cultural Capability - Promoting the Discipline:Marking Boundaries and Crossing Borders Proceedings of the conference at Leeds Metropolitan University Dec. 1998, pp. 405-420.( Ilson, 1991).

John Read (2004). 7. RESEARCH IN TEACHING VOCABULARY.Annual Review of Applied Linguistics, 24, pp 146-161. doi:10.1017/S0267190504000078.

Lewis, M. (1993).The Lexical Approach.Language Teaching Publications.

Laufer, B. \& P. Nation. (1999). A vocabulary size test of controlled productive ability.Language Testing 16, 3351.

Linse, C. T. \&Nunan, D. (Ed). (2005). Practical english language teaching: Young learners. New York: McGrawHill ESL/ELT.

Maximo, R. (2000). Effects if rote, context, keyword, and context/ keyword method onretention of vocabulary in EFL classroom, Language Learning, 50, 2, 385-412.

McCarthy, M. J. (1988). Some vocabulary patterns in conversation. In R. A. Carter and M. J. 
Meara, P. (1980). Vocabulary acquisition: A neglected aspect of language learning. Language Teaching and Linguistics Abstracts, 13, 221-246.

Mompean, J. A. (2005). Taking advantage of phonetic symbols in the efl classroom.[Online].Availableat: http://www.phon.ucl.ac.uk/home/johnm/ptlc2005/pdf/ptlcp28.pdf [December, 16, 2012]

Nation, I. S. P. (1990).Teaching and learning vocabulary. Boston, Mass.: Heinle\&Heinle Publishers.

Nation, P. (Ed.). (1994). New ways in teaching vocabulary.Alexandria, VA: TESOL.

Nation, I. S. P. (2001).Learning vocabulary in another language. Cambridge: Cambridge University Press.

(Neuman, S. B., \& Dwyer, J. (2009).Missing in action: Vocabulary instruction in pre-k. The Reading Teacher, 62(5), 384-392.

Oxford, R. L. (1990). Language Learning Strategies. What Every Teacher should know. Boston: Heinle and 323 Heinle.

Pinter, A. (2006). Teaching young language learners. Oxford: Oxford University Press.

Prince, P. (1996) 'Second language vocabulary learning: The role of context versus translations as a function of proficiency'. The Modern Language Journal, 80(4), pp. 478-493.

Read, J. (2000). Assessing vocabulary. United Kingdom: Cambridge University Press.

Reed, D. K. (2012). Why teach spelling? Portsmouth, NH: RMC Research Corporation, Center on Instruction.

Read, J. (2000). Assessing vocabulary. Cambridge: Cambridge University Press.

Reed, D. K. (2012). Why teach spelling? Portsmouth, NH: RMC Research Corporation, Center on Instruction

Schmitt, N. (1997). Vocabulary learning strategies. In Schmitt, N. and McCarthy, M. (eds.)Vocabulary:Descriptive, Acquisition and Pedagogy. Cambridge: Cambridge University Press.

Schmitt, N., \&Meara, P. (1997).Researching vocabulary through a word knowledge framework: word association and verbal suffix.Studies in Second Language Acquisition 19, 17-36.

Schmitt, N. (1999). The relation between TOEFL vocabulary items and meaning, association, 325 collocation, and word-class knowledge. Language Testing 16, 189-216

Schmitt, N. (2000). Vocabulary in language teaching. Cambridge: Cambridge University Press.

Schmitt, N., and M. J. McCarthy (Eds.) (1997). Vocabulary: Description, Acquisition and Pedagogy. Cambridge: Cambridge University Press.

Sime, Daniela (2001). The use and perception of illustrators in the foreign language classroom. In Cavé, Christian, Isabelle Guaïtella, \& Serge Santi (Eds.) Oralitéetgestualité. Interactions etc omportementsmultimodauxdans la communication (pp. 582-585). Paris: L'Harmattan

Stuart, W., (2005) : Receptive and productive vocabulary learning: The Effects of Reading and Writing on Word Knowledge, Studies in Second Language Acquisition / Volume 27 / Issue 01 / March, pp 33-52

Stuart, W., (2008) : Receptive and productive vocabulary size of L2 learners, Studies in Second Language Acquisition / Volume 30 / Issue 01 / March, pp 79 - 95

Takač, V. P., \& Singleton, D. (Eds.).(2008). Vocabulary learning strategies and foreign language acquisition.Canada: Multilingual Matters Ltd.

Tellier, Marion (2007). How do teacher's gestures help young children insecond languageacquisition? Proceedings of the meeting of International Society of Gesture Studies, ISGS 2005:Interacting Bodies, June, 15th-18th, ENS Lyon, France. http://gesture- Iyon2005.enslsh. fr/IMG/pdf/TellierFINAL.pdf

Teller, Marion., (2008). The effect of gestures on second language memorisation by young children.Gesture, John Benjamins Publishing, 8 (2), pp.219-235.<hal-00375251>

Taylor \& Francis (2014). Measurement Instrumentation, and Sensors Handbook CRC Press. 
Thorburry, S. (2002). How to teach vocabulary. England:Pearson Education Limited.Ur, P., (1998). A course in language teaching.Cabridge University Press.

Walters, J.D. (2006) 'Methods of teaching inferring meaning from context'. RELC Journal, 37(2), pp. 176-190.

Walters, J.M. (2004) 'Teaching the use of context to infer meaning: A longitudinal survey of L1 and L2 vocabulary research'. Language Teaching, 37(4), pp. 243-252.

Webb, S.A. and Chang, A.C.S. (2012) 'Second Language Vocabulary Growth'.RELCJournal, 43(1), pp. 113126. 